\title{
Rational Analysis on the Synergistic Development between Specialty Construction of Higher Vocational Colleges and Local Industry Development
}

\author{
Xiaoqiong Liu \\ Meishan Vocational and Technical College, Meishan Sichuan, 620010, China
}

Keywords: Higher vocational colleges, Specialty construction, Industrial development.

\begin{abstract}
The mission of higher vocational colleges is to cultivate technical and skilled personnel for industrial development. The specialty structure of higher vocational colleges should be consistent with the structure of the local industry. Its specialty construction should be consistent with industrial development. The two should support each other and make progress together. From a rational point of view, this paper analyzes the problems in higher vocational colleges and industrial development, and puts forward the basic ideas of the synergistic and progressive development between specialty construction and industrial development from macroscopical, meso and microcosmic level.
\end{abstract}

\section{Introduction}

With the implementation of major national strategies such as "Made in China 2025", "Internet +", "Mass Entrepreneurship and Innovation", "Targeted Poverty Reduction", and "Belt and Road", the higher vocational and technical education faces a new situation. The State Council, the Ministry of Education and other relevant ministries have formulated a series of policies and documents on strengthening higher vocational and technical education for the future development of higher vocational colleges and the major problems they face. They have clearly pointed out that higher vocational and technical colleges should take strengthening moral education and cultivating people as the basis, the development of the industry as the objective, and promoting employment as the direction, so as to improve the quality of personnel training comprehensively.

\section{The Importance of the Collaborative Development between Specialty Construction and Industrial Development}

\subsection{Specialty construction is inseparable from industrial development}

Since its establishment, the basic duty of higher vocational colleges is to train high-quality technical and skilled talents for industrial development. Industrial development is the basis of specialty construction in higher vocational colleges. The development and upgrading of local industries will inevitably lead to the transformation and development of personnel training in local higher vocational colleges. The level of industrial development determines the level of specialty development in local higher vocational colleges, and the adjustment of local industrial structure determines the adjustment of the specialty structure of local higher vocational colleges. The position structure of the enterprises in the industry and the requirement specifications of the talents dominate the construction of faculty, equipment and facilities, construction of the curriculum system, and the formulation of training objectives concerning specialty construction. To do a good job and train qualified personnel of higher vocational education, higher vocational colleges must keep abreast of industrial development, investigate the needs of enterprises in the industry timely, and carry out the talent training of school-enterprise cooperation and production-education integration. Teachers' teaching should be consistent with job requirements. The construction of experimental training equipment and facilities should fully consider the status of industrial development. Students should go to the enterprises to do internships, accept training and find jobs. Students, teachers, courses, classes and other factors are all inseparable from the industry. 


\subsection{Specialty construction provides an important support for industrial restructuring and upgrading}

The key of social economy and industrial development lies in human resources. With the advancement of science and technology, the demand for human resources for economic and industrial development is getting higher and higher, requiring laborers to master advanced technologies and be more intelligent. Higher vocational colleges just came into being in order to realize this realistic requirement. It serves the industrial development directly and train applied talents with high quality and solid technical skills for the industry. From a foreign perspective, the rapid rise of Germany's economy and industry after the war has benefited from its vocational education. Some people refer to the training of "Dual System" professionals in Germany as the "secret weapon" of Germany's economic development. From the domestic point of view, as the frontier of reform and opening up, Shenzhen took a short 30 years to become a manufacturing center and a science and technology center, which also benefited from the nationwide vocational education and personnel delivery. Therefore, the quality of higher vocational colleges affects the quality of talents in industrial development. At the same time, the good conduct of specialty construction of higher vocational colleges can also provide an important research force for industrial transformation.

\section{Problems in Specialty Construction and Industrial Development in Higher Vocational Colleges}

\subsection{The specialty structure in higher vocational colleges is not in full consistency with the industrial structure}

As a direct service industry, vocational colleges provide high-level industrial workers for industrial development. The specialty structure of colleges should be adjusted in time so as to be consistent with the industrial restructuring. At present, vocational colleges are mainly in two forms, industry-hosted vocational colleges and locally hosted vocational colleges. Industry-hosted colleges should focus on industry development to adjust the specialty structure, and locally-hosted vocational colleges should be adjusted according to the needs of local economic and social development to set up majors, in order to meet the needs of technical and skilled talents for the development of local industries. However, there are a lot of unsatisfactory situations currently. Various types of higher vocational colleges have a very high repetition rate in their major setting. The major setting of industry-hosted vocational colleges is beyond the industry. While the major setting in local higher vocational colleges hardly consider the local social and economic development plan. In a sense, the locally hosted higher vocational colleges cover a wider range of majors, which brings much pressure to the running of higher vocational colleges.

\subsection{The talent training plan is too general to be in consistency with the needs of local industrial positions}

Talent training program is the top-level design of professional personnel training, which includes training objectives, training specifications, training path design, training system structure, assessment methods and other basic provisions. However, problems do exist in talent training program of higher vocational colleges. The low consistency with the demand of industrial positions is a major problem.

First of all, training objectives and training specifications need careful study. What kind of talents should a major train needs in-depth study. For the same specialty in different regions, due to the different levels of industrial development, the training objectives should be quite different. In eastern and the western region, there is a big gap between the development of industries and the demand for qualified personnel. While formulating training objectives and training specifications, an in-depth industry and enterprise research should be carried out to understand the requirements of industry and business personnel. Only by clarifying the needs, can the setting of training objectives and training specifications meet the needs of docking positions. Therefore, it is necessary for the industry and enterprises to participate thoroughly, to set training objectives and develop specifications accurately. 
Only qualified personnel training programs which are scientific and in line with industrial development can produce qualified technical and skilled personnel who meet the needs.

Second, the cultivation system needs the participation of industries and enterprises and should be set up scientifically. At present, the cultivation system of higher vocational colleges still adopts the curriculum system, which divides the cultivation of technical and skilled talents into curriculum systems of different qualities. Some of them still adopt the three-stage curriculum system of public courses, specialized courses and extension courses, while some divide the course system into a three-type one, including public courses, professional theory courses and professional practice courses. It is not difficult to see that there is still a deep discipline system existing in the talent training programs in higher vocational colleges, and it has not yet gone out discipline range. Relevant documents of national vocational education have repeatedly emphasized that personnel training work in higher vocational education should emphasize the theories-sufficiency scale, highlight technical skills training and take skill training as the core. This is not only the requirements of classroom teaching, but also the requirements of the design of talent training program. Program design should give full consideration to the field of professional learning. Each learning area may exist the integration of traditional courses, therefore, it also requires the in-depth participation of industry experts so as to really cultivate technical and skilled talents that meet the needs of industrial development.

From the perspective of training path design, higher vocational colleges attach great importance to college training and enterprise training. The training path of "school-enterprise co-education and dualistic subject" is very well designed, but in fact it is just empty talks. As we all know, since the implementation of relevant national policies is difficult, enterprises lack the motivation to participate in vocational education. School-enterprise cooperation is based on the balance of interests of both schools and enterprises, but in the short term, the interests of enterprises and vocational colleges cannot be seen clearly. Therefore, higher vocational colleges are highly enthusiastic, but enterprises lack enthusiasm, so it is difficult to achieve in-depth school-enterprise cooperation. "Jointly formulating programs, implementing teaching together, jointly carrying out curriculum construction and jointly building training conditions" are mainly at the ideological level, and are not well implemented.

\subsection{The construction of professional experimental training facilities in higher vocational colleges is inconsistent with the reality of industries and enterprises}

Under the guiding ideology of "ability-based ability and outstanding technical skills", higher vocational colleges have put a lot of money into the construction of experimental training facilities in schools. In particular, during the construction of model colleges and universities and the construction of key institutions, the experimental training facilities in many higher vocational colleges are very good. However, there are still a lot of higher vocational colleges which lack training and experimental facilities. More importantly, the experimental training facilities are built under the traditional mode of thinking, and are far away from the actual situation of the enterprise. Students can operate proficiently in the experimental training room, but when stepping into the real field, they are lost and need a second time training. Therefore, productive experimental facilities jointly built by the enterprises and schools are a very good way which needs the participation of the industries and enterprises.

\section{The Rational Analysis of the Synergistic Development between Specialty Construction of Higher Vocational Colleges and Industrial Development}

\subsection{On macro-level, we should strengthen policy research to promote the specialty development of higher vocational colleges and the progress of industrial development}

In 2014, the State Council promulgated the "Decision on Accelerating the Development of Modern Vocational Education". It explicitly proposed that vocational education and economic and social development should be planned in a synchronized manner so as to promote long-term 
convergence between education and teaching reform and industrial restructuring. The synergy between the specialty construction and industrial development in higher vocational colleges has got macroscopic policy support. However, to truly realize the synergy and progress, it is necessary to intensify the study of specific policies at the macro level and take the undertaking of vocational education as a basic part of the social responsibility of industries and enterprises, and improve the enthusiasm and initiative of enterprises to participate in the specialty construction of higher vocational colleges. It is also possible to consider choosing the educational enterprises and determining the standards for being an educational enterprise. The state gives policy support to education enterprises in various aspects, and the vocational colleges and education enterprises carry out in-depth cooperation so as to truly realize the integration of production and teaching.

\subsection{Give full play to the leading function of local government, promote the integration and development of higher vocational colleges and local industry, and make progress together from a meso level}

We should give full play to the leading function of local government, bring industry, enterprises and higher vocational colleges together to establish the appropriate supporting policies and systems, so that industries and enterprises can take the initiative to integrate into the specialty construction of higher vocational colleges at all levels, and vocational institutions can take the initiative to participate in the development of applied research in industries and enterprises, so as to improve business processes and product quality.

Local governments should, in light of the actual economic and social development in the region, set up policy support to encourage and support enterprises to build and share productive training bases with higher vocational colleges, and organically integrate enterprise production, teacher research and student training. Local governments should encourage technical experts of the enterprises to participate in the teaching of higher vocational colleges, encourage teachers in higher vocational colleges to integrate into the production and operation of enterprises, and let school-enterprise realize the double integration of personnel, resources sharing, co-management of production and co-management of teaching and learning.

Local government should actively carry out the mission of vocational education collectivization advocated by State Council and the Ministry of Education. Leading by local government and considering the development of local industries, industries, enterprises and higher vocational colleges should establish a vocational education group which conforms to the development of this region. A long-term operation mechanism should be established to achieve the coordinated progress between specialty construction of higher vocational colleges and local industry development.

\subsection{Higher vocational colleges should deepen their specialty construction, set up their own characteristics and standards, provide talent support and technical support for industrial development, and promote industrial transformation and upgrading from a micro level}

\subsubsection{A professional assessment mechanism should be established to dynamically adjust majors and achieve coordination between specialty structure and local industrial structure.}

In 2015, the Ministry of Education issued a notice on establishing the diagnosis and improvement system of teaching work in vocational colleges. Higher vocational colleges should take this as an opportunity to establish a professional evaluation mechanism to diagnose all aspects of specialty construction and personnel training and promote professional development of specialty construction, so as to meet the needs of the development of local industries. Majors which are in low conformity with the development of local industries should be eliminated to achieve the coordination between the specialized structures and local industrial structures.

\subsubsection{The construction of productive training base in school should be strengthened based on professional norms and standards}

The training bases in school are the basic conditions for the cultivation of skilled personnel. Vocational colleges should fully study the professional norms and standards in the construction of 
training facilities in schools so as to ensure the practicability, advancement and the conformity with the production frontlines. The same setting with the workplace should be built, so that students could experience the future work environment in school and shorten their adaptation period of employment as much as possible. The construction of training base is best to be carried out by cooperating with enterprises and should be built into a productive one. The production of enterprises should be put into teaching process, and the production standards should be studied by the students, so as to cultivate the students' sense of responsibility and quality. By doing so, the integration of production and education, the "craftsmanship" spirit of the unity of knowing and doing and learning-by-doing can be achieved.

\subsubsection{Innovate teacher management mechanism to create a high level of teaching staff}

Whether there is a high-level teacher team in higher vocational colleges is the key to whether the specialty construction and industrial development can make progress together. From practical experience, the key to the in-depth cooperation between school and enterprise under the current policy environment is whether the teachers in higher vocational colleges could solve technical problems for the industries and enterprises and whether to bring direct economic interests to business production and management. Higher vocational colleges should continually innovate the management mechanism of teachers, enhance external thrust, stimulate internal forces, build teachers' professional skills and teaching levels through multiple channels, encourage and support teachers to deepen their studies in industries and enterprises, and promote scientific research and technology promotion application.

\section{References}

[1] Document of the State Council, No. 19 (2014), "Decision of the State Council on Speeding up the Development of Modern Vocational Education".

[2] Document of Department of Professional Education and Adult Education of the Ministry of Education, No. 4 (2015), "Opinions of the Ministry of Education on Further Promoting Group Education in Vocational Education".

[3] Liu Jingjing, Mechanism and Path of Higher Vocational Colleges Serving Local Economic Development, Adult Education. 2013.4.

[4] Du Xiangpei, Study on Local Higher Vocational Colleges Serving Local Economic Development, Career and Education, 2010.27. 